\title{
PERSEPSI WISATAWAN TERHADAP KEBERADAAN OBJEK WISATA AIR TERJUN DI DUSUN JEMBONG
}

\author{
Kadek Suarnayasa ${ }^{1}$, lyus Akhmad Haris ${ }^{2}$ \\ Jurusan Pendidikan Ekonomi \\ Universitas Pendidikan Ganesha \\ Singaraja, Indonesia \\ e-mail: kadeksuarnayasa@gmail.com¹, akhmad.haris@undiksha.ac.id²

\begin{abstract}
Abstrak
Tujuan penelitian ini adalah untuk mengetahui persepsi wisatawan terhadap keberadaan objek wisata Air Terjun Jembong ditinjau dari dimensi atraksi, aksesibilitas, fasilitas dan organisasi pengelola. Jenis penelitian ini adalah deskriptif. Populasi dalam penelitian ini adalah seluruh pengunjung objek wisata Air Terjun Jembong. Sampel di tentukan sebanyak 100 orang yang diambil dengan menggunakan teknik incidental sampling. Data dikumpulkan dengan kuesioner dan dianalisis secara deskriptif. Hasil penelitian menunjukkan bahwa 1) persepsi wisatawan terhadap keberadaan objek wisata Air Terjun Jembong ditinjau dari dimensi atraksi dikategorikan setuju dengan total skor sebesar 3.923 yang berada antara 3.780 - 4.500. 2) persepsi wisatawan terhadap keberadaan objek wisata Air Terjun Jembong ditinjau dari dimensi aksesibilitas dikategorikan setuju dengan total skor sebesar 2.557 yang berada antara 2.520 - 3000. 3) persepsi wisatawan terhadap keberadaan objek wisata Air Terjun Jembong ditinjau dari dimensi fasilitas dikategorikan setuju dengan total skor sebesar 6.359 yang berada antara $6.300-$ 7.500. 4) persepsi wisatawan terhadap keberadaan objek wisata Air Terjun Jembong ditinjau dari dimensi organisasi pengelola dikategorikan setuju dengan total skor sebesar 3.221 yang berada antara $2.719-3.359$.
\end{abstract}

Kata kunci: Wisatawan, Objek Wisata Air Terjun Jembong, Persepsi.

\begin{abstract}
The purpose of this study is to determine the perception of tourists to the existence of Jembong Waterfall in terms of attraction dimension, accessibility amenity, and ancillary services. This type of research is descriptive. The population in this study is all visitors Jembong Waterfall tourist attraction. The sample was determined as many as 100 people were taken using incidental sampling technique. Data were collected by questionnaire and analyzed descriptively. The results showed that 1) the perception of tourists to the existence of Jembong Waterfall in terms of attraction dimension are categorized agree with a total score of 3,923 which is between 3,780 4,500 . 2) the perception of tourists to the existence of Jembong Waterfall in terms of accessibility dimension categorized agree with a total score of 2,557 located between $2,520-3000$. 3) the perception of tourists to the existence of Jembong Waterfall in terms of amenity dimension categorized agreed with a total score of 6,359 located between $6,300-7,500$. 4) perception of tourists to the existence of Jembong Waterfall in terms of ancillary services dimension categorized agree with a total score of 3,221 located between 2,719 - 3,359.
\end{abstract}

Keywords : Tourist, Attractions Jembong Waterfall, Perception

\section{PENDAHULUAN}

Persepsi merupakan suatu konsep

dalam ilmu psikologi yang menyatakan sebuah proses individu dalam menginterprestasikan kesan-kesan sensoris mereka guna mengartikan arti bagi lingkungan mereka. Walgito (2004) menyatakan persepsi merupakan suatu 
proses yang didahului oleh proses diterimanya stimulus oleh individu melalui alat indera atau disebut juga proses sensoris. Persepsi akan mempengaruhi perilaku seseorang dalam melakukan proses penilain terhadap objek atau keadaan tertentu yang ada di lingkungannya. Apabila persepsi seseorang positif terhadap suatu objek maka perilaku seseorang akan positif terhadap objek yang dipersepsikan. Begitu juga sebaliknya, apabila persepsi seseorang negatif terhadap suatu objek maka perilaku seseorang akan negatif terhadap objek yang dipersepsikannya. Sebuah objek wisata harus memiliki empat aspek utama diantaranya attraction (atraksi), accessibility (aksesibilitas), amenity (fasilitas), dan ancillary services. Di Dusun Jembong, Desa Ambengan, Kecamatan Sukasada, Kabupaten Buleleng terdapat objek wisata yaitu air Terjun Jembong. Air Terjun Jembong berada di daerah perbukitan dengan pemandangan alam yang hijau dan sejuk. Jaraknya sekitar 6 kilometer dari kota Singaraja dan memiliki pemandangan desa yang menyuguhkan panorama hamparan persawahan. Dahulu sebelum bernama Desa Ambengan oleh masyarakat setempat disebut dengan nama Desa Sukadana. Karena banyak tumbuh ilalang (Ambengan) yang tumbuh diwilayah desa sehingga dinamakan Desa Ambengan sampai sekarang. Awalnya air terjun tersebut hanya berupa telaga biasa yang memiliki debit air yang besar. Lamakelamaan warga berinisiatif untuk menata keberadaan air tersebut hingga dikenal sampai sekarang. Karena letaknya diatas bukit, pengunjung perlu berjalan kaki sekitar 200 meter dari tempat parkir. Sampai pos penjagaan untuk membayar tiket masuk, pengunjung hanya dikenakan dana sukarela untuk menyumbang seikhlasnya. Ketika berjalan kaki di jalan setapak ini, pengunjung akan menjumpai hamparan perkebunan coklat dan cengkeh di kanan dan kiri jalan dipinggir sungai. Tak perlu tenaga ekstra untuk naik atau turun tangga menuju lokasi. Jalan yang dibangun berupa tangga ataupun jalan setapak sudah tertata rapi sehingga tidak menyulitkan pengunjung untuk menyusuri setiap jalannya. Sesampai di lokasi, hanya pemandangan hijau dan asri yang terlihat serta aliran dan guyuran air di air Terjun Jembong yang muncul dari balik bebatuan.

Air Terjun Jembong berbeda dengan air terjun lainnya. Aliran air terjun tidak tegak lurus seperti tempat lainnya, tapi mengalir dalam kemiringan 75 derajat, sehingga air terjatuh tidak terdengan bergemuruh karena mengalir pada tebing tinggi. Serta Keunikannya terdapat pada penataan taman untuk keindahan di lokasi wisata. Di kawasan Air Terjun Jembong ini taman-taman ditata sangat rapi dan terjaga dengan baik. Berkunjung ke air Terjun Jembong pengunjung bisa menikmati suasana lebih relaks, tenang, dan damai. Dibawah air terjun terdapat sebuah kolam renang yang sangat jernih dengan kedalaman sekitar satu meter, pengunjung bisa mandi dan bermain sepuasnya dikolam tersebut. Air kolam yang dingin dan bening, sangat menggoda siapapun untuk mandi di kolam tersebut. Selain itu terdapat keunikan tersendiri terdapat pada yang ditata dibawah lokasi air terjun. Kolam tersebut diberi nama Kolam Selfie. Kolam berbentuk hati dengan air yang jernih merupakan salah satu tujuan utama pengunjung disamping untuk melihat air terjun. Rencana nantinya kolam tersebut akan dikembangkan kembali agar dapat digunakan sebagai tempat prawedding bagi masyarakat. Melihat keasrian yang dimiliki air Terjun Jembong, menarik banyak wisatawan untuk datang ke lokasi tersebut. Pengunjung yang datang dominan adalah wisatawan domistik pada hari libur.

Namun objek wisata yang ada di Bali tidak hanya Air Terjun Jembong masih banyak objek wisata lainnya. Persaingan antar objek wisata yang semakin ketat menyebabkan perkembangan objek wisata air Terjun Jembong terlihat semakin menurun dibanding dengan objek wisata lainnya. Hal ini terlihat dari hari-hari kunjungan dan jumlah wisatawan yang berkunjung masih sedikit.

Pada tahun 2016 jumlah kunjungan wisatawan yang berkunjung ke air terjun di Dusun Jembong mengalami pasang surut 
bahkan terus menurun. Pada bulan Januari jumlah kunjungasn wisatawan sebesar 453 orang, pada bulan Pebruari jumlah pengunjung mengalami penurunan sebesar 119 orang, pada bulan Maret jumlah pengunjung juga mengalami penurunan sebesar 26 Orang. Dan begitu juga pada bulan April, Mei, Juni, Juli, sampai dengan Agustus yang terus megalami penurunan jumlah pengunjung. Pada bulan September jumlah pengunjung mengalami peningkatan sebesar 142 orang sehingga jumlah pengunjung pada bulan September menjadi 450 orang. Akan tetapi pada bulan Oktober, November dan Desember jumlah pengunjung kembali mengalami penurunan berkisar antara 200 sampai dengan 345 orang. Dengan hal ini pengelola terus mengembangkan objek wisata air Terjun Jembong dengan membangun kolam renang yang baru selesai dibangun pada 11 April 2017. Sejak berdirinya kolam renang jembong, wisatawan yang datang terus meningkat terutama pada hari libur. Air kolam renang Jembong langsung mengalir dari air terjun yang membuat air kolam menjadi segar dan jernih tanpa bahan kimia yang biasanya di pakai pada kolam renang pada biasanya. Hal ini membuat wisatawan yang berkunjung sangat tergoda untuk mandi di kolam renang. Wisatawan yang datang merasa puas berkunjung karena susananya yang nyaman, sejuk, tenang, dan air yang sejuk membuat wisatawan yang berkunjung ke air terjun dan kolam renang di Dusun Jembong, berkunjung kembali.

Oleh karena itu dalam rangka untuk mengembangkan objek wisata air Terjun Jembong maka perlu diketahui persepsi wisatawan terhadap keberadaan air terjun di Dusun Jembong, Desa Ambengan, Kecamatan Sukasada Kabupaten Buleleng.

Persepsi merupakan suatu konsep dalam ilmu psikologi yang menyatakan sebuah proses individu dalam menginterprestasikan kesan-kesan sensoris masing-masing diri individu guna mengartikan arti bagi lingkungannya. Menurut Slameto (2010) persepsi adalah proses yang menyangkut masuknya pesan atau informasi ke dalam otak manusia. Ikhsan (2008) mendefinisikan persepsi sebagai suatu proses dimana individu-individu mengorganisasikan dan menafsirkan kesan indera mereka agar memberi makna kepada lingkungan mereka. Melalui persepsi tersebut seseorang memiliki pandangan tersendiri terkait objek atau kejadian yang di persepsinya.

$$
\text { Menurut walgito (2004) }
$$

menyatakan bahwa proses terjadinya perspsi seseorang melalui beberapa tahap, pertama proses fisik sebagai bentuk proses stimulus mengenai alat indera (reseptor) melalui saraf-saraf sensoris, kedua proses fisiologis sebagai bentuk proses diteruskannya stimulus yang diterima oleh alat indera melalui syaraf sensorik ke otak, ketiga proses psikologis sebagai bentuk proses timbulnya kesadaran individu yang terjadi di otak sebagai pusat kesadaran, sehingga individu menyadari apa yang dilihat, apa yang didengar atau apa yang diraba, dan keempat hasil yang diperoleh dari proses persepsi yaitu tanggapan dan perilaku. Jadi persepsi itu awalnya merupakan proses di tangkapnya stimulus oleh indera manusia dan diteruskan stimulus tersebut oleh indera melalui saraf-saraf manusia. Stimulus yang diterima oleh reseptor menyebabkan individu sadar dengan stimulus yang diterima sehingga individu mempunyai tanggapan dan perilaku terkait stimulus tersebut. Tanggapan yang diberikan oleh individu satu dengan yang lainnya berbeda sesuai dengan keadaan individu.

Setiap individu memiliki gambaran yang berbeda mengenai realitas di sekelilingnya. Begitu pula persepsi antara individu berbeda antara satu dengan yang lainnya. Mulyana (2000) mengemukakan bahwa prinsip penting mengenai munculnya persepsi adalah sebagai berikut. Pertama Persepsi berdasarkan pengalaman, kedua persepsi bersifat selektif, ketiga Persepsi bersifat dugaan, keempat persepsi bersifat evaluatif, kelima persepsi bersifat kontekstual. Persepsi individu berbeda dengan persepsi individu lain, hal ini dikarenakan persepsi tersebut muncul dari pengalaman itu sendiri. 
Persepsi bersifat selektif sehingga individu hanya memperhatikan apa yang diperhatikan olehnya. Persepsi dapat digunakan sebagai loncatan dari kesimpulan dikarenakan individu dapat menafsirkan suatu berdasarkan pengalaman yang telah diterimanya. Sehingga persepsi memiliki sifat evaluatif yang mencerminkan sikap, kepercayaan, dan nilai dimana konteks di dalamnya meliputi struktur objek atau kejadian menjadi salah satupengaruh palig kuat memunculkan persepsi. Menurut Sarwono (2002) Persepsi merupakan proses pencarian informasi untuk dipahami maka alat untuk memperoleh informasi tersebut adalah pengindraan. Proses penginderaan berlangsung setiap saat, pada waktu individu menerima stimulus melalui alat indera, yaitu melalui mata sebagai alat penglihatan, telinga sebagai alat pendengar, hidung sebagai alat pembauan, lidah sebagai alat pengecap, dan kulit sebai alat peraba. Alat indera tersebut merupakan alat penghubung individu dengan lingkungan luar. Stimulus yang diidera itu kemudian diorganisasikan dan diinterprestasikan, sehingga individu menyadari dan mengerti tentang apa yang diindera itu.

$$
\text { Menurut Walgito (2004) }
$$

mengemukakan beberapa faktor yang dapat mempengaruhi persepsi, yaitu pertama objek yang dipersepsikan, Objek menimbulkan stimulus yang mengenai alat indera atau reseptor. Stimulus dapat datang dari luar individu yang bersangkutan langsung mengenai syaraf penerima bekerja sebagai reseptor, namun sebagian terbesar stimulus datang dari luar individu. Kedua alat indera, syaraf, dan pusat susunan syaraf, Alat indera atau reseptor merupakan alat untuk menerima stimulus. Di samping itu juga harus ada syaraf sensoris sebagai alat untuk meneruskan stimulus yang diterima reseptor ke pusat susunan syaraf, yaitu otak sebagai pusat kesadaran dan sebagai alat untuk mengadakan respon diperlukan syaraf motoris. Ketiga perhatian, Untuk mengadakan persepsi diperlukan adanya perhatian. Perhatian merupakan pemusatan atau kosentrasi dari seluruh aktivitas individu yang ditunjukkan kepada sesuatu atau kumpulan objek. Dari hal-hal tersebut dapat dikemukakan bahwa untuk mengadakan persepsi adanya beberapa faktor yang berperan yang merupakan syarat terjadinya persepsi, yaitu objek yang dipersepsikan, alat indera syaraf dan pusat susunan syaraf, dan perhatian. Senada dengan pernyataan tersebut, Shaleh (2008) menyatakan beberapa faktor yang mempengaruhi persepsi. Adapun faktor-faktor yang dapat mempegaruhi persepsi, yaitu perhatian yang selektif, ciri-ciri rangsangan, nilai dan kebutuhan individu, pengalaman dahulu.

Pengukuran persepsi dapat dilakukan dengan menggunakan skala likert. Menurut Djaali (2008) skala likert adalah skala yang dapat digunakan untuk mengukur sikap, pendapat dan persepsi seseorang atau sekelompok orang tentang suatu gejala atau fenomena. Dalam meneliti persepsi seseorang terhadap suatu objek atau peristiwa, maka menggunakan skala likert 1 - 5, yaitu dengan pilihan sangat setuju (SS) memperoleh skor 5, setuju (S) memperoleh skor 4, cukup setuju (CS) memperoleh skor 3, tidak setuju (TS) memperoleh skor 2, dan sangat tidak setuju (STS) memperoleh skor 1.

\section{Menurut Sammeng}

wisatawan adalah orang yang melakukan perjalanan atau kunjungan sementara secara sukarela ke suatu tempat di luar lingkungan tempat tinggalnya sehari-hari untuk suatu maksud tertentu dan tidak memperoleh penghasilan tetap di tempat yang di kunjunginya. Menurut Marpaung (2002:36) membagi wisatawan kedalam tiga bagian, yaitu pengunjung, wisatawan, dan darmawisata. Adapun pengertian pengunjung adalah setiap orang yang berhubungan ke suatu negara lain, dimana seseorang mempunyai tempat kediaman, dengan alasan melakukan pekerjaan yang diberikan oleh negara yang dikunjunginya. Sedangkan Wisatawan adalah setiap orang yang bertempat tinggal di suatu negara tanpa memandang kewarganegaraannya, berkunjung kesuatu tempat pada negara yang sama untuk waktu lebih dari 24 jam, 
dan Darmawisata atau excursionist adalah pengunjung sementara yang menetap kurang dari 24 jam di negara yang dikunjungi, termasuk orang yang berkeliling dengan kapal pesiar. Berdasarkan pendapat mengenai wisatawan, maka dapat disimpulkan bahwa wisatawan adalah orang yang melakukan suatu perjalanan dari daerah asal menuju daerah lain dengan tujuan tertentu dan periode tertentu. Wisatawan dibagi atas pengunjung, wisatwan, dan darmawisata.

Menurut Cooper dalam Pitana (2012) diungkapkan bahwa sebuah tujuan wisata diperkenalkan dan dijual, terlebih dahulu harus mengkaji 4 aspek utama yang harus dimiliki, yaitu: pertama attraction atau atraksi adalah produk utama sebuah tujuan wisata, kedua accessibility atau aksesibilitas adalah sarana dan infrastruktur untuk menuju tujuan wisata. Akses jalan raya, ketersediaan sarana transportasi dan rambu-rambu penunjuk jalan merupakan aspek penting bagi sebuah destinasi, ketiga amenity adalah segala fasilitas pendukung yang bisa memenuhi kebutuhan dan keinginan wisatawan selama berada di destinasi. Amenitas berkaitan dengan ketersediaan sarana akomodasi untuk menginap serta restoran atau warung untuk makan dan minum, keempat ancillary services berkaitan dengan ketersedian sebuah organisasi atau orang-orang yang mengelola tujuan wisata. Ini menjadi penting karena walaupun tujuan wisata sudah mempunyai atraksi, aksesibilitas, dan amenitas yang baik, tapi jika tidak ada yang mengelola maka ke depannya pasti akan terbengkalai. Organisasi sebuah tempat tujuan wisata akan melakukan tugasnya seperti sebuah perusahaan.

Menurut SK. Menparpostel No.: KM. 98 / PW.102 / MPPT-87, objek wisata adalah semua tempat atau keadaan alam yang memiliki sumber daya wisata yang dibangun dan dikembangkan sehingga mempunyai daya tarik dan diusahakan sebagai tempat yang dikunjungi wisatawan. Menurut Wardiayatna (2010) objek wisata adalah sesuatu yang menjadi pusat daya tarik wisatawan dan dapat memberikan kepuasan pada wisatawan. Dari pengertian objek wisata menurut beberapa ahli, maka peneliti dapat menyimpulkan bahwa objek wisata adalah tempat yang memiliki sumber daya wisata yang dibangun dan dikembangkan sehingga memiliki daya tarik bagi orang untuk menunjungi tempat tersebut.

Menurut Undang-undang Republik Indonesia No. 10 tahun 2009, daya tarik wisata dijelaskan sebagai segala sesuatu yang memiliki keunikan, kemudahan, dan nilai yang berupa keanekaragaman kekayaan alam, budaya, dan hasil buatan manusia yang menjadi sasaran atau kunjungan wisatawan. Sedangkan menurut UU No. 9 tahun 1990 tentang kepariwisataan disebutkan bahwa daya tarik wisata adalah suatu yang menjadi sasaran wisata terdiri dari: daya tarik wisata ciptaan Tuhan Yang Maha Esa, daya tarik wisata hasil karya manusia, dan daya tarik minat khusus. Daya tarik wisata ciptaan Tuhan Yang Maha Esa yang berwujud keadaan alam, flora dan fauna. Daya tarik wisata hasil karya manusia yang berwujud museum, peninggalan sejarah, seni dan budaya, wisata agro, wisata buru, wisata petualangan alam, taman rekreasi dan kelompok hiburan. Dan Daya tarik minat khusus, seperti: berburu, mendaki gunung, gua, industri dan kerajinan, tempat perbelanjaan, sungai air deras, tempat-tempat ibadah, tempat ziarah dan lain-lain.

\section{METODE}

Penelitian ini dilakukan di Dusun Jembong, Desa Ambengan, Kabupaten Buleleng, Provinsi Bali. Jenis data yang digunakan dalam penelitian ini adalah data kualitatif. Data kualitatif dalam penelitian ini yakni persepsi wisatawan terhadap keberadaan objek wisata air terjun di Dusun Jembong. Sumber data yang digunakan dalam penelitian ini adalah data primer. Data primer dalam penelitian ini yaitu hasil kuesioner yang diisi oleh wisatawan yang berkunjung ke Air Terjun Jembong.

Instrumen penelitian ini berupa kuisioner untuk memperoleh data mengenai persepsi wisatawan terhadap keberadaan objek wisata air terjun di 
Dusun Jembong. Variabel akan diukur dengan model pendekatan skala likert.

Dalam melakukan penelitian, peneliti menggunakan metode kuesioner. Kuesioner digunakan untuk memperoleh data tentang persepsi wisatawan terhadap keberadaan objek wisata air terjun jembong. Dalam penelitian ini kuesioner dibagikan kepada 100 orang wisatawan yang berkunjung yang dijadikan sampel penelitian dari seluruh populasi wisatawan yang berkunjung ke objek wisata Air Terjun Jembong. Teknik pengambilan sampel menggunakan teknik incidental sampling. Sedangkan kuesioner mengguanakan skala likert yang terdiri dari 5 (lima) pilihan jawaban kepada responden, yaitu pertama Sangat Tidak Setuju (STS), kedua Tidak Setuju (TS), ketiga Cukup Setuju (CS), keempat Setuju (S), dan kelima Sangat Setuju (SS).

Teknik analisis data yang digunakan dalam penelitian ini adalah analisi deskriptif. analisis deskriptif digunakan untuk mendeskripsikan persepsi wisatawan terhadap keberadaan objek wisata Air Terjun Jembong. Menurut Irianto (2004), untuk memperoleh skala interval persepsi dilakukan langkahlangkah sebagai berikut.

Pertama menentukan skor terendah dan skor tertinggi dari keseluruhan alternatif jawaban.

$$
\begin{aligned}
& \text { skor } r_{\max }=\text { nilai maksimal } \mathrm{x} \text { jumlah } \\
& \text { pertanyaan } \quad x \quad \text { jumlah } \\
& \text { responden } \\
& \text { skor }_{\min }=\text { nilai minimal } \mathrm{x} \text { jumlah } \\
& \text { pertanyaan } \quad x \quad \text { jumlah } \\
& \text { responden }
\end{aligned}
$$

Kedua menentukan interval persepsi wisatawan terhadap keberadaan objek wisata Air Terjun Jembong

$$
\begin{aligned}
& \text { Interval } \\
& \text { skortertingi-skortarendah }
\end{aligned}
$$

Dari langkah-langkah yang telah dijelaskan di atas maka menghasilkan kriteria persepsi sebagai berikut.

Tabel 1. Kriteria total skor persepsi wisatawan terhadap keberadaan objek wisata air terjun jembong ditinjau dari dimensi atraksi

\begin{tabular}{cl}
\hline Rentang Skor & \multicolumn{1}{c}{ Kategori } \\
\hline $3.780-4.500$ & Sangat Setuju \\
$3.059-3.779$ & Setuju \\
$2.338-3.058$ & Cukup Setuju \\
$1.617-2.337$ & Tidak Setuju \\
$896-1.616$ & Sangat Tidak Setuju \\
\hline
\end{tabular}

Kriteria persepsi dengan total skor 896 - 1.616, maka persepsi wisatawa terhadap keberadaan objek wisata Air Terjun Jembong ditinjau dari dimensi atraksi dinyatakan sangat tidak setuju. Kriteria persepsi dengan total skor 1.617 2.337 dinyatakan tidak setuju. Kriteria persepsi dengan total skor 2.338 - 3.058 dinyatakan cukup setuju. Kriteria persepsi dengan total skor 3.059 - 3.779 dinyatakan setuju, dan jika kriteria persepsi dengan total skor $3.780-4.500$, maka persepsi wisatawan terhadap keberadaan objek wisata Air Terjun Jembong ditinjau dari dimensi atraksi dinyatakan sangat setuju.

Tabel 2. Kriteria total skor persepsi wisatawan terhadap keberadaan objek wisata air terjun jembong ditinjau dari dimensi aksesibilitas

\begin{tabular}{cc} 
Rentang Skor & Kategori \\
\hline & Sangat Setuju \\
$2.520-3.000$ & Setuju \\
$2.039-2.519$ & Cukup Setuju \\
$1.558-2.038$ & Tidak Setuju \\
$1.077-1.557$ & Sangat Tidak Setuju \\
$597-1.076$ & \\
\hline
\end{tabular}

Kriteria persepsi dengan total skor 597-1.076, maka persepsi wisatawa terhadap keberadaan objek wisata Air Terjun Jembong ditinjau dari dimensi aksesibilitas dinyatakan sangat tidak setuju. Kriteria persepsi dengan total skor 1.077-1.557 dinyatakan tidak setuju. Kriteria persepsi dengan total skor 1.5582.038 dinyatakan cukup setuju. Kriteria persepsi dengan total skor 2.039-2.519 dinyatakan setuju, dan jika kriteria persepsi dengan total skor 2.520-3.000, maka persepsi wisatawan terhadap keberadaan objek wisata Air Terjun 
Jembong ditinjau dari dimensi aksesibilitas dinyatakan sangat setuju.

Tabel 3. Kriteria total skor persepsi wisatawan terhadap keberadaan objek wisata air terjun jembong ditinjau dari dimensi amenity

\begin{tabular}{ll}
\hline Rentang Skor & \multicolumn{1}{c}{ Kategori } \\
\hline $6.300-7.500$ & Sangat Setuju \\
$5.099-6.299$ & Setuju \\
$3.898-5.098$ & Cukup Setuju \\
$2.697-3.897$ & Tidak Setuju \\
$1.496-2.696$ & Sangat Tidak Setuju \\
\hline
\end{tabular}

Kriteria persepsi dengan total skor 1.496 - 2.696, maka persepsi wisatawa terhadap keberadaan objek wisata Air Terjun Jembong ditinjau dari dimensi amenity dinyatakan sangat tidak setuju. Kriteria persepsi dengan total skor 2.697 3.897 dinyatakan tidak setuju. Kriteria persepsi dengan total skor 3.898 - 5.098 dinyatakan cukup setuju. Kriteria persepsi dengan total skor 5.099 - 6.299 dinyatakan setuju, dan jika kriteria persepsi de ngan total skor j.300 - 7.500, maka persepsi wisatawan terhadap keberadaan objek wisata Air Terjun Jembong ditinjau dari dimensi amenity dinyatakan sangat setuju.

Tabel 4. Kriteria total skor persepsi wisatawan terhadap keberadaan objek wisata air terjun jembong ditinjau dari dimensi Ancallary Services

\begin{tabular}{cl}
\hline Rentang Skor & \multicolumn{1}{c}{ Kategori } \\
\hline $3.360-4.000$ & Sangat Setuju \\
$2.719-3.359$ & Setuju \\
$2.078-2.718$ & Cukup Setuju \\
$1.437-2.077$ & Tidak Setuju \\
$796-1.436$ & Sangat Tidak Setuju \\
\hline
\end{tabular}

Kriteria persepsi dengan total skor 796 - 1.436, maka persepsi wisatawa terhadap keberadaan objek wisata Air Terjun Jembong ditinjau dari dimensi Ancallary Services dinyatakan sangat tidak setuju. Kriteria persepsi dengan total skor 1.437 - 2.077 dinyatakan tidak setuju. Kriteria persepsi dengan total skor 2.078 - 2.718 dinyatakan cukup setuju.
Kriteria persepsi dengan total skor 2.719 3.359 dinyatakan setuju, dan jika kriteria persepsi dengan total skor $3.360-4.000$, maka persepsi wisatawan terhadap keberadaan objek wisata Air Terjun Jembong ditinjau dari dimensi Ancallary Services dinyatakan sangat setuju

\section{HASIL DAN PEMBAHASAN}

Berdasarkan perhitungan yang dilakukan dengan perbandingan skala interval yang diperoleh, maka dapat diketahui tingkat persepsi wisatawan terhadap keberadaan objek wisata air terjun jembong ditinjau dari dimensi atraksi sebagai berikut.

Tabel 5. Hasil analisis data persepsi wisatawan terhadap keberadaan objek wisata air terjun di Dusun Jembong ditiniau dari dimensi atraksi

\begin{tabular}{|c|c|c|c|}
\hline Dimensi & Skor & $\begin{array}{c}\text { Skala } \\
\text { Interval }\end{array}$ & Kategori \\
\hline Atraksi & $\begin{array}{c}3.92 \\
3\end{array}$ & $3.780-$ & Sangat \\
\hline Total & $\begin{array}{c}3.92 \\
3\end{array}$ & $\begin{array}{l}3.780- \\
4.500\end{array}$ & $\begin{array}{l}\text { Sangat } \\
\text { Setuju }\end{array}$ \\
\hline
\end{tabular}

Hasil penelitian menunjukkan bahwa dimensi atraksi diperoleh skor sebesar 3.923. skor 3.923 sesuai dengan hasil perhitungan skala interval persepsi berada pada skala interval 3.780- 4.500, sehingga persepsi dikatakan sangat setuju, Hal ini berarti wisatawan setuju bahwa pemandangan alam di Air Terjun Jembong sangat indah, Air Terjun Jembong memiliki keunikan tersenderi berbeda dengan objek wisata yang lain karena taman-taman di tata sangat rapi dan di jaga dengan baik. Selain itu yang membuat Air Terjun Jembong berbeda dengan yang lain yaitu aliran air terjun tidak tegak lurus seperti ailiran air terjun pada umumnya, tapi mengalir pada kemiringan 75 derajat sehingga air yang terjatuh tidak terdengar bergemuruh. Udara sejuk yang berhembus membuat wisatawan yang berkunjung nyaman dan betah berada di air terjun. Air Terjun Jembong memiliki wahana pendukung seperti kolam selfie, kolam renang, dan tracking yang menambah daya tarik wisatawan untuk berkunjung ke Air Terjun 
Jembong. Selain itu wisatawan juga berpendapat sangat setuju bahwa keamanan wisatawan terjaga saat menikmati wahana pendukung yang tersedia dan juga lingkungan di sekitar objek wisata sangat bersih.

Tabel 6. Hasil analisis data persepsi wisatawan terhadap keberadaan objek wisata air terjun di Dusun Jembong ditinjau dari dimensi aksesibilitas

\begin{tabular}{lccc}
\multicolumn{1}{c}{ Dimensi } & Skor & $\begin{array}{c}\text { Skala } \\
\text { Interval }\end{array}$ & Kategori \\
\cline { 2 - 4 } Aksesibilita & 2.55 & $2.520-$ & Sangat \\
S & 7 & 3000 & Setuju \\
Total & 2.55 & $2.520-$ & Sangat \\
& 7 & 3000 & Setuju \\
\hline
\end{tabular}

Hasil penelitian menunjukkan bahwa dimensi aksesibilitas diperoleh skor 2.557. skor 3.923 sesuai dengan hasil perhitungan skala interval persepsi berada pada skala interval 3.780-4.500, sehingga persepsi dikatakan sangat setuju, Hal ini berarti wisatawan setuju bahwa jarak objek wisata Air Terjun Jembong tidak begitu jauh dari pusat Kota Singaraja. Tempat ini bisa dijangkau dalam 2 jam perjalanan mobil dari arah Denpasar, sedangkan dari objek wisata Bedugul hanya $15 \mathrm{~km}$. Jalan menuju objek wisata yang menuju objek wisata tersedia dan mudah di jangkau, sertai kualitas jalan dalam kondisi baik dan tidak ada hambatan lalu lintas untuk menuju objek wisata Air Terjun Jembong.

Tabel 7. Hasil analisis data persepsi wisatawan terhadap keberadaan objek wisata air terjun di Dusun Jembong ditinjau dari dimensi amenity

\begin{tabular}{cccc}
\hline Dimensi & Skor & $\begin{array}{c}\text { Skala } \\
\text { Interval }\end{array}$ & Kategori \\
\cline { 2 - 4 } Amenity & 6.359 & $6.300-$ & Sangat \\
& & 7.500 & Setuju \\
Total & 6.359 & $6.300-$ & Sangat \\
& & 7.500 & Setuju \\
\hline
\end{tabular}

Hasil penelitian menunjukkan sebesar 6.359. skor 6.359 sesuai dengan hasil perhitungan skala interval persepsi berada pada skala interval $6.300-7.500$, sehingga persepsi dikatakan sangat setuju, Hal ini berarti wisatawan setuju bahwa terdapat toilet di area objek wisata, jumlah toilet yang memadai dan terjaga kebersihannya serta tersedia air bersih di dalam toilet. Terdapat rest area (tempat istirahat) untuk para wisatawan yang membutuhkan, selain itu terdapat lahan parkir dengan luas parkir yang memadai. $\mathrm{Di}$ area objek wisata tersedia tempat sampah agar wisatawan yang berkunjung tidak membuang sampah sembarangan serta terdapat warung makan, kualitas makanan yang disediakan layak untuk di konsumsi dan harga makanan yang ditawarkan terjangkau oleh wisatawan.

Tabel 8. Hasil analisis data persepsi wisatawan terhadap keberadaan objek wisata air terjun di Dusun Jembong ditinjau dari dimensi Ancillary Services

\begin{tabular}{|c|c|c|c|}
\hline Dimensi & Skor & $\begin{array}{c}\text { Skala } \\
\text { Interval }\end{array}$ & Kategori \\
\hline $\begin{array}{l}\text { Ancillary } \\
\text { Services }\end{array}$ & 3.221 & $\begin{array}{c}2.719- \\
3.359\end{array}$ & Setuju \\
\hline Total & 3.221 & $\begin{array}{c}2.719- \\
3.359\end{array}$ & Setuju \\
\hline
\end{tabular}

Hasil penelitian menunjukkan bahwa dimensi Ancillary Services diperoleh skor sebesar 3.221. skor 3.221sesuai dengan hasil perhitungan skala interval persepsi berada pada skala interval $2.719-3.359$, sehingga persepsi dikatakan setuju, Hal ini berarti wisatawan setuju bahwa harga tiket masuk ke objek wisata Air Terjun Jembong terjangkau oleh wisatawan. Petugas yang ada di objek wisata ramah dan sopan, petugas juga selalu bersedia menolong saat wisatawan yang berkunjung mengalami kesulitan dan kecepatan petugas saat menangani keluhan wisatawan.

\section{Pembahasan}

Berdasarkan hasil penelitian menunjukkan bahwa persepsi wisatawan terhadap keberadaan objek wisata air terjun di Dusun Jembong ditinjau dari dimensi atraksi menunjukkan kategori 
sangat setuju. Adapun hasil penelitian diperoleh skor dimensi atraksi sebesar 3.923. skor 3.923 berada pada skala interval $3.780-4.500$ yang menunjukkan bahwa persespsi di kategorikan sangat setuju. Hal ini berarti wisatawan setuju bahwa pemandangan alam di Air Terjun Jembong, sangat indah, Air Terjun Jembong memiliki keunikan tersenderi berbeda dengan objek wisata yang lain karena taman-taman di tata sangat rapi dan di jaga dengan baik. Selain itu yang membuat Air Terjun Jembong berbeda dengan yang lain yaitu aliran air terjun tidak tegak lurus seperti ailiran air terjun pada umumnya, tapi mengalir pada kemiringan 75 derajat sehingga air yang terjatuh tidak terdengar bergemuruh. Udara sejuk yang berhembus membuat wisatawan yang berkunjung nyaman dan betah berada di air terjun. Air Terjun Jembong memiliki wahana pendukung seperti kolam selfie, kolam renang, dan tracking yang menambah daya tarik wisatawan untuk berkunjung ke Air Terjun Jembong. Selain itu wisatawan juga berpendapat sangat setuju bahwa keamanan wisatawan terjaga saat menikmati wahana pendukung yang tersedia dan juga lingkungan di sekitar objek wisata sangat bersih. Atraksi wisata yang unik, menarik dan beragam jenisnya pasti akan menarik wisatawan untuk berkunjung ke objek wisata tersebut. Selain itu, pastikan keamanan wisatawan saat bermain di atraksi pendukung agar pengunjung merasa aman dan nyaman menikmati atraksi pendukung yang di sediakan.

Sedangkan persepsi wisatawan terhadap keberadaan objek wisata air terjun di Dusun Jembong ditinjau dari dimensi aksesibilitas menunjukkan kategori sangat setuju. Adapun hasil penelitian di peroleh skor dimensi aksesibilitas sebesar 2.557. Skor 2.557 berada pada skala interval $2.520-3000$ yang menunjukkan bahwa persepsi dikategorikan sangat setuju $\mathrm{Hal}$ ini berarti wisatawan setuju bahwa jarak objek wisata Air Terjun Jembong tidak begitu jauh dari pusat Kota Singaraja. Tempat ini bisa dijangkau dalam 2 jam perjalanan mobil dari arah Denpasar, sedangkan dari objek wisata Bedugul hanya $15 \mathrm{~km}$. Jalan menuju objek wisata yang menuju objek wisata tersedia dan mudah di jangkau, sertai kualitas jalan dalam kondisi baik dan tidak ada hambatan lalu lintas untuk menuju objek wisata Air Terjun Jembong. Selain itu terdapat papan petunjuk jalan yang jelas yang diletakkan di tempat srategis membuat wisatawan mudah untuk menuju objek wisata Air Terjun Jembong. Aksesibilitas merupakan alat vital dalam industri pariwisata. Kemudahan untuk mencapai objek wisata salah satu faktor pendukung pengembangan objek wisata. Kualitas jalan yang baik dan tersedia papan petunjuk jalan akan membantu wisatawan mudah untuk menemukan lokasi objek wisata. Aksesibilitas yang kurang layak akan mengganggu kegiatan pariwisata.

Sedangkan persepsi wisatawan terhadap keberadaan objek wisata air terjun di Dusun Jembong ditinjau dari dimensi amenity (fasilitas) menunjukkan kategori sangat setuju. Adapun hasil penelitian di peroleh skor dimensi amenity sebesar 6.359. skor 6.359 berada pada skala interval $6.300-7.500$ yang menunjukkan bahwa persepsi dikategorikan sangat setuju. Hal ini berarti wisatawan setuju bahwa terdapat toilet di area objek wisata, jumlah toilet yang memadai dan terjaga kebersihannya serta tersedia air bersih di dalam toilet. Terdapat rest area (tempat istirahat) untuk para wisatawan yang membutuhkan, selain itu terdapat lahan parkir dengan luas parkir yang memadai. $\mathrm{Di}$ area objek wisata tersedia tempat sampah agar wisatawan yang berkunjung tidak membuang sampah sembarangan serta terdapat warung makan, kualitas makanan yang disediakan layak untuk di konsumsi dan harga makanan yang ditawarkan terjangkau oleh wisatawan. Fasilitas pelengkap di lokasi objek wisata akan meningkatkan kualitas objek wisata. Fasilitas pelengkap sangat dibutuhkan oleh wisatawan selama melakukan kegiatan wisata. Fasilitas objek wisata sebagai faktor pendukung kegiatan pariwisata tidak dapat diabaikan. Kekuatan daya tarik wisata yang dimiliki oleh suatu objek wisata mungkin tidak akan berarti tanpa adanya fasilitas 
pendukung yang memadai fasilitas objek wisata harus tertata sedemikian rupa agar keberadaan fasilitas pelengkap objek wisata tidak melemahkan daya tarik wisata yang disajikan oleh objek wisata tersebut.

Sedangkan persepsi wisatawan terhadap keberadaan objek wisata air terjun di Dusun Jembong ditinjau dari dimensi ancallary services menunjukkan kategori setuju. Adapun hasil penelitian di peroleh skor dimensi ancallary services sebesar 3.221. skor 3.221 berada pada skala interval 2.719 - 3.359 yang menunjukkan bahwa persepsi dikategorikan setuju. Hal ini berarti wisatawan setuju bahwa harga tiket masuk ke objek wisata Air Terjun Jembong terjangkau oleh wisatawan. Petugas yang ada di objek wisata ramah dan sopan, petugas juga selalu bersedia menolong saat wisatawan yang berkunjung mengalami kesulitan dan kecepatan petugas saat menangani keluhan wisatawan. Selain itu petugas selalu memberikan informasi yang jelas kepada wisatawa dan selalu memberikan salam dan senyuman kepada wisatawan yang berkunjung. Pelayanan petugas objek wisata mempengaruhi kenyamanan dan kepuasan wisatawan saat melakukan kegiatan wisata dan juga menentukan kualitas objek wisata. Pelayanan sangat penting, karena pelayanan mempengaruhi juga terhadap kepuasan wisatawan berkunjung ke suatu objek wisata. Pelayanan yang kurang baik terhadap wisatawan akan menimbulkan wisatawan enggan berkunjung kembali ke objek wisata tersebut.

\section{SIMPULAN DAN SARAN}

Berdasarkan hasil penelitian dan pembahasan, maka dapat di simpulkan sebagai berikut. Pertama persepsi wisatawan terhadap keberadaan objek wisata air terjun di Dusun Jembong ditinjau dari dimensi atraksi dikategorikan sangat setuju, bahwa pemandangan Air Terjun Jembong sangat indah dan memiliki keunikan tersendiri. Udara yang berhembus sangat sejuk, serta air terjun memiliki wahana pendukung seperti kolam selfie, kolam renang, dan tracking. Selain itu kebersihan di sekitar air terjun sangat terjaga. Kedua persepsi wisatawan terhadap keberadaan objek wisata air terjun di Dusun Jembong ditinjau dari dimensi aksesibilitas dikategorikan sangat setuju, bahwa jarak objek wisata air terjun tidak begitu jauh dari pusat Kota Singaraja, jalan menuju objek wisata tersedia dan mudah di jangkau, serta kualitas jalan menuju objek wisata dalam kondisi baik dan terdapat papan petunjuk jalan yang jelas yang di letakkan di tempat strategis. Ketiga persepsi wisatawan terhadap keberadaan objek wisata air terjun di Dusun Jembong ditinjau dari dimensi Amenity dikategorikan sangat setuju, bahwa terdapat fasilitas seperti toilet, rest area (tempat istirahat), lahan parkir, tempat sampah dan juga terdapat warung makan. keempat persepsi wisatawan terhadap keberadaan objek wisata air terjun di Dusun Jembong ditinjau dari dimensi ancillary services dikategorikan setuju, bahwa harga tiket masuk ke air terjun terjangkau oleh wisatawan, petugas objek wisata ramah dan sopan dalam melayani wisatawan yang berkunjung, serta selalu memberikan informasi yang mudah dimengerti wisatawan.

\section{Saran}

Berdasarkan simpulan hasil penelitian dan pembahasan tersebut, maka dalam penelitian ini dapat dikemukakan saran yaitu bagi pengelola diberikan arahan tentang pengembangan Air Terjun Jembong yaitu dengan menambah wahana pendukung yang menarik dan terus menjaga kebersihan sekitar air terjun jembong. Bagi akademik diharapkan nantinya bagi peneliti lain yang ingin melakukan penelitian di bidang pariwisata diharapkan mampu menganalisis dan membandingkan pengembangan pariwisata dengan penelitian lainnya untuk memperoleh solusi yang terbaik dalam mengembangkan pariwisata yang ada di Bali atau daerah lainnya. Selain itu penelitian ini perlu di kembangkan dengan referensi lainnya agar penelitian selanjutnya di bidang pariwisata dapat dikembangkan dengan baik. 


\section{DAFTAR PUSTAKA}

Cooper. (2012). Tourism, principles and practice. London: logam.

Djaali. 2008. Psikologi Pendidikan. Jakarta: PT. Bumi Aksara

Ikhsan, Arfan. 2008. Metodelogi Penelitian Akuntansi Keperilakuan. Yogyakarta: Graha Ilmu.

Irianto, Agus. 2004. Statistik Konsep Dasar dan Aplikasinya. Jakarta: PT. Bumi Aksara.

Marpaung, H. 2002. Pengetahuan Kepariwisataan Edisi Revisi. Bandung: Alfa Beta.

Mulyana, Deddy. 2000. IImu Komunikasi Suatu Pengantar. Bandung: PT. Remaja Rosda Karya.

Surat Keputusan. Menparpostel No:: KM. $98 /$ PW.102/ MPPT-87. Pengertian objek wisata. Di akses dari http://id.m.wikipedia.org.

Slameto. 2010. Belajar Dan Faktor Raktor Yang Mempengaruhinya. Jakarta: Rineka Cipta.

Sammeng, Andi Mappi.2002. Cakrawala Pariwisata. Jakarta: Balai Pustaka.

Sarwono, Sarlito Wirawan. 2002. Psikologi Sosial. Jakarta: Balai Pustaka.

Shaleh, Abdul Rahman. 2008. Psikologi. Jakarta: Kencana Prenada Media Group.

Undang-undang Republik Indonesia Nomor 10 tahun 2009 tentang Kepariwisataan.

Undang-undang Republik Indonesia Nomor 9 tahun 1990 tentang Kepariwisataan.

Walgito, Bimo. 2004. Pengantar Psikologi Umum. Yogyakarta: Andi.

Wardiyatna. 2010. Metode penelitian pariwisata. C.V ANDI OFFSET. 